\title{
UJI TOKSISITAS LOGAM BERAT TERHADAP BENUR UDANG WINDU (Penaeus monodon) DAN NENER BANDENG (Chanos chanos)
}

\author{
Rachmansyah $^{*}$, Dalfiah ${ }^{*}$, P.R. Pongmasak ${ }^{*}$ dan Taufik Ahmad ${ }^{*}$
}

\begin{abstract}
ABSTRAK
Perkembangan usaha budidaya perikanan dewasa ini berlangsung bersamaan dengan perkembangan industri yang cenderung menghasilkan bahan pencemar sebagai limbah. Efek toksisitas bahan pencemar logam terhadap benur windu (Penaeus monodon) dan nener bandeng (Chanos chanos) sebagai komoditas potensial budidaya perlu dikaji. Uji toksisitas diaplikasikan dalam penelitian ini. Hewan uji berupa pascalarva udang windu, $P$. monodon dan nener bandeng, C. chanos, masing-masing berbobot rata-rata $0,2766 \pm 0,0115 \mathrm{~g} /$ ekor dan $0,4656 \pm 0,1317 \mathrm{~g} / \mathrm{ekor}$, dimasukkan ke dalam wadah bak gelas fiber transparan berbentuk segi empat, diisi air bersalinitas $20-25$ ppt sebanyak 20 liter, dan dilengkapi dengan aerasi. Logam berat yang diuji adalah $\mathrm{Hg}, \mathrm{Cd}, \mathrm{Cu}, \mathrm{Pb}, \mathrm{Ni}$, dan $\mathrm{Cr}$

Penelitian dilakukan dalam dua tahap, yaitu uji pendahuluan untuk mencari nilai ambang atas dan ambang bawah, kemudian dilanjutkan dengan uji toksisitas (LC 50-96jam) dengan menguraikan konsentrasi ambang atas dan bawah secara logaritma. Analisis probit digunakan untuk mencari nilai LC50 pada waktu pemaparan 24, 48, 72, dan 96 jam. Peubah kualitas air media meliputi suhu, salinitas, $\mathrm{pH}$, dan oksigen terlarut dianalisis pada awal penelitian, setiap 24 jam sebelum pergantian air media dan akhir percobaan. Nilai peubah kualitas air dianalisis secara deskriptif untuk menilai kelayakan habitat bagi hewan uji.
\end{abstract}

Hasil penelitian menunjukkan bahwa urutan tingkat toksisitas logam berat terhadap benur windu adalah $\mathrm{Hg}>\mathrm{Cd}>\mathrm{Cu}>\mathrm{Pb}>\mathrm{Ni}>\mathrm{Cr}$, masing-masing LC50-96jam adalah 0,0840; 0,8796; 1,$8139 ; 14,5267 ; 19,8420$; dan $22,8268 \mathrm{ppm}$. Sedangkan urutan toksisitas untuk nener bandeng adalah $\mathrm{Hg}>\mathrm{Cu}>\mathrm{Cd}>\mathrm{Cr}>\mathrm{Ni}>\mathrm{Pb}$, masing-masing nilai LC50-96jam adalah 1,5444; 3,9316; 14,$7659 ; 40,7021 ; 86,9257$; dan 245,7488 ppm. Dikaji dari nilai LC50-96 jam, baku mutu limbah cair bagi kegiatan industri yang beroperasi (SK Menteri Negara LH No.Kep-51/MENLH/10/1995), perlu direvisi, khususnya mengenai kadar $\mathrm{Hg}$ dan $\mathrm{Cu}$ yang dijinkan.

ABSTRACT: Toxicity of heavy metals on post larvae of tiger prawn (Penaeus monodon Fabricius) and milkfish (Chanos chanos Forskal) fry. By: Rachmansyah, Dalfiah, P.R. Pongmasak and Taufik Ahmad.

Toxicity test of heavy metals on the prawn and milkfish fry which are the main fish protein sources become a necessity to anticipate product quality awareness. The toxicity test with semi static system was applied. Post larvae of tiger prawn and milkfish fry, weighted $0.2766 \pm 0.0115 \mathrm{~g} / \mathrm{ind}$. and $0.4656+0.1317 \mathrm{~g} /$ ind, respectively, were stocked in a $23 \mathrm{~L}$ transparant fibre glass tank, filled with $20 \mathrm{~L}$ filter water at $20-25 \mathrm{ppt}$ salinity and aerated. Heavy metals tested were $\mathrm{Hg}, \mathrm{Cd}, \mathrm{Cu}, \mathrm{Pb}$, $\mathrm{Ni}$, and $\mathrm{Cr}$.

The test were conducted in two phases. The first test was meant to determine the LC0-48 hours and LC100-24 hours, and the second test was carried out to determine the LC50-96hours. Probit analysis was used to calculate the LC50 at 24, 48, 72, and 96 hours exposure. Water quality parameters such as temperature, $p H$, dissolved oxygen, and salinity were analysed in the beginning and every 24 hours before replacement of total test media, and at the end of the experiment. The order of acute toxicity (LC50-96hour) from high to low for $\mathrm{Hg}, \mathrm{Cd}, \mathrm{Cu}, \mathrm{Pb}, \mathrm{Ni}$, and $\mathrm{Cr}$ on post larvae of tiger prawn were $0.0840,0.8796,1.8139,14.5267,19.8420$, and $22.8268 \mathrm{ppm}$, respectively. The LC50-96hour values for $\mathrm{Hg}, \mathrm{Cu}, \mathrm{Cd}, \mathrm{Cr}, \mathrm{Ni}$, and $\mathrm{Pb}$, on milkfish fry were 1.5444, 3.9316, 14.7659, $40.7021,86.9257$, and $245.7488 \mathrm{ppm}$, respectively. Based on this findings, it seems that waste water

Teneliti pada Balai Penelitian Perikanan Pantai 
quality criteria for industrial activity issued by MENLH should be revised, especially in the Hg and $\mathrm{Cu}$ allowable concentration.

\section{KEYWORDS: Toxicity, heavy metals, Median Lethal Concentration, tiger prawn, milkfish.}

\section{PENDAHULUAN}

Wilayah pesisir sebagai kawasan perikanan budidaya rentan terhadap dampak dari kegiatan sektoral baik dari wilayah hulu maupun hilir. Salah satu limbah kegiatan sektoral yang berdampak penting terhadap kualitas lingkungan hidup perikanan adalah logam berat. Meskipun telah ada ketentuan baku mutu limbah cair bagi kegiatan industri (SK Menteri Negara Lingkung. an Hidup No:KEP-51/MENLH/10/1995), namun kadar maksimum beberapa logam berat yang diperbolehkan diduga masih berada di atas nilai aman bagi kehidupan organisme perairan terutama krustase dan ikan yang bernilai ekonomis penting. Di sisi lain, usaha pembangunan perikanan pantai mutlak memerlukan prasyarat lingkungan perairan yang berkualitas sesuai kebutuhan kelayakan hidup organisme budidaya. Adanya buangan limbah yang mengandung logam berat secara berkesinambungan cepat atau lambat akan mengakibatkan kerusakan ekosistem perikanan pantai.

Pencemaran logam berat dapat merusak lingkungan perairan dalam hal stabilitas, keanekaragaman dan kedewasaan ekosistem (Baurdeau \& Threshou dalam Heath, 1987). Dari aspek ekologis, kerusakan ekosistem perairan akibat pencemaran logam berat ditentukan oleh faktor kadar dan kesinambungan polutan yang masuk dalam perairan, sifat toksisitas, bioakumulasi dan persistensinya baik terhadap proses fisik, kimia maupun biologi. Pencemaran logam berat akan menyebabkan terjadinya perubahan struktur komunitas perairan, jaringan makanan, tingkah laku, efek fisiologi, genetik dan resistensi (Moriarty, 1987). Pencemaran perairan oleh logam berat selain berpengaruh terhadap kehidupan organisme akuatik dan kerusakan lingkungan hidup perikanan pantai juga membawa akibat buruk terhadap kesehatan manusia akibat mengkonsumsi hasil laut yang telah tercemar. Adanya perdagangan global menuntut pasok produk perikanan yang bebas cemaran. Hasil pemantauan Hutagalung (1989) dan Hutagalung et al. (1993) melaporkan bahwa sebagian kerang hijau Mytilus viridis yang dibudidayakan di perairan Pulau Onrust dan Ancol, Teluk Jakarta mengandung logam berat $\mathrm{Hg}$ dan $\mathrm{Cd}$ melebihi nilai ambang batas. Rachmansyah et al. (1997), mendapatkan kandungan logam dalam daging udang windu yang diperoleh dari tambak di pantai Barat Sulawesi Selatan masing-masing mencapai $13,36 \mathrm{ppm} \mathrm{Pb}$ dan 28,90 ppm $\mathrm{Cu}$. Sementara baku mutu yang diijinkan untuk produk ikan yang dikonsumsi masing-masing 2,0 ppm $\mathrm{Pb}$ dan 20,0 ppm Cu (SK. Dirjen Pengawasan Obat dan Makanan No.03725/SK/ VII/89).

Setiap sistem perairan memiliki kapasitas daya terima yang terbatas terhadap polutan. Kadarnya dalam lingkungan meningkat seiring dengan peningkatan jumlah pemakaian dalam berbagai kegiatan atau proses peluruhan batuan induk dan sedimen secara alamiah. Sebagai contoh penggunaan $\mathrm{Pb}$ sebagai zat tambahan pada bahan bakar dan pigmen cat, merupakan penyebab utama peningkatan jumlah kadar $\mathrm{Pb}$ di lingkungan (Frank, 1995). Sampai pada batas tertentu yang melebihi daya dukung lingkungan, maka keberadaan logam berat dapat bersifat racun bagi organisme perairan. Konsentrasi logam berat yang mematikan organisme akuatik tergantung pada sifat logam berat dan organisme itu sendiri (Canli \& Furness, 1993), serta toksisitasnya bervariasi di antara berbagai spesies (Bryan, 1971). Krustase dapat meningkatkan toleransinya terhadap logam berat sampai batas tertentu sebagai respon kehidupannya dalam perairan yang tercemar (Canli \& Furness, 1993).

Keracunan logam berat dapat bersifat akut yang disebabkan oleh kontaminasi pada dosis tinggi, sedangkan keracunan kronis umumnya disebabkan oleh kontaminasi dalam kadar yang rendah dan waktu pemaparan yang lama. Connel \& Miller (1995) menyatakan bahwa uji toksisitas akut sangat berguna untuk mengkaji berbahayanya zat kimia terhadap kehidupan di air. Udang windu dan ikan bandeng sebagai salah satu komoditas andalan di subsektor perikanan cukup peka terhadap pencemaran logam berat, terutama pada fase awal kehidupan. Karena itu, diperlukan informasi nilai toksisitas beberapa 
logam berat terhadap kehidupan benur windu dan nener bandeng sebagai bahan acuan dalam menetapkan atau meninjau kembali baku mutu limbah cair bagi kegiatan industri sehingga lingkungan perairan bagi pemanfaatan dan pengelolaan wilayah pesisir yang rasional dapat terwujud. Hal ini sesuai dengan ketentuan baku mutu limbah cair bagi kegiatan industri yang perlu ditinjau secara berkala sekurangnya sekali dalam lima tahun (Pasal 2 ayat $7 \mathrm{KepMen} \mathrm{LH} \mathrm{No:}$ Kep-51/MENLH/10/1995) sebagai upaya pengendalian pembuangan limbah cair ke lingkungan.

Penelitian bertujuan untuk mengetahui besarnya toksisitas letal (LC50-96jam) beberapa logam berat terhadap kehidupan benur windu ( $P$. monodon) dan nener bandeng (C. chanos), sebagai upaya mengkaji berbahayanya logam berat terhadap kehidupan organisme perairan.

\section{BAHAN DAN METODE}

Percobaan dilakukan di Laboratorium Basah Instalasi Tambak Percobaan Maranak, Balai Penelitian Perikanan Pantai, Maros. Wadah percobaan berupa bak gelas fiber transparan volume 23 liter yang dilengkapi aerasi dan masingmasing diisi air media bersalinitas 20-25 ppt sebanyak 20 liter. Perlengkapan aerasi dimaksudkan untuk memasok kebutuhan oksigen dalam media percobaan.

Hewan uji berupa pascalarva udang windu $(P$. monodon) dan nener bandeng (C. chanos) diperoleh dari tempat penampungan benur dan nener yang berlokasi di Kabupaten Maros dan Pangkep. Ukuran benur dan nener masing-masing berbobot rataan $0,2766 \pm 0,0115$ g/ekor dan $0,4656 \pm 0,1317$ g/ekor. Sebelum digunakan untuk percobaan, hewan uji diaklimatisasi terlebih dahulu selama satu minggu. Selama proses aklimatisasi pakan berupa pelet sebanyak $10 \%$ bobot biomassa diberikan dua kali sehari pada pukul 08.00 dan 16.00. Setelah proses aklimatisasi, hewan uji diseleksi berdasarkan kondisi kesehatan yaitu tidak cacat, berukuran seragam dan memiliki pergerakan normal. Kepadatan hewan uji adalah 20 ekor per wadah percobaan. Bahan uji logam berat dalam bentuk senyawa, adalah $\mathrm{Hg}\left(\mathrm{HgCl}_{2}\right)$, $\mathrm{Cd}\left(\mathrm{CdCl}_{2}\right), \mathrm{Ni}\left(\mathrm{NiCl}_{2}\right), \mathrm{Cr}\left(\mathrm{CrO}_{3}\right), \mathrm{Pb}\left(\left(\mathrm{CH}_{3} \mathrm{COO}\right)_{2}\right.$ $\left.\left.\mathrm{Pb}_{3} \mathrm{H}_{2} \mathrm{O}\right)\right), \mathrm{Cu}\left(\mathrm{CuSO}_{4} 5 \mathrm{H}_{2} \mathrm{O}\right)$. Konsentrasi logam berat sebagai perlakuan dalam media uji dihitung dari bobot molekul logam berat dalam senyawa kimia tersebut.
Metode bioassay semi statis mengacu pada Anonimous (1983) diaplikasikan dalam percobaan dan dilakukan dalam dua tahapan, yaitu uji pendahuluan untuk menentukan konsentrasi ambang atas dan ambang bawah, kemudian dilanjutkan dengan uji toksisitas akut untuk menentukan nilai Median Lethal Concentration (LC50) pada waktu pemaparan 24, 48, 72, dan 96 jam.

Uji pendahuluan yang berlangsung selama 48 jam tanpa pergantian air, bertujuan untuk mengetahui konsentrasi ambang letal yaitu ambang atas (LC100-24jam) atau (N) dan ambang bawah (LC0-48jam) atau (n). Ambang atas adalah konsentrasi terendah di mana semua hewan uji mati dalam waktu aplikasi 24 jam, sedangkan konsentrasi ambang bawah adalah konsentrasi tertinggi di mana semua hewan uji hidup dalam waktu aplikasi 48 jam. Konsentrasi logam berat yang digunakan dalam uji pendahuluan adalah 0 ppm (kontrol), 10 $0^{-2}, 10^{1}, 10^{\circ}, 10,10,10 \mathrm{ppm}$, masing-masing perlakuan diulang 3 kali. Pengamatan mortalitas hewan uji dilakukan pada jam ke-2, 4, 8, 16, 24, dan 48 .

Pada uji toksisitas akut (LC50-96 jam) perlakuan konsentrasi logam berat dibuat dengan menguraikan secara logaritma nilai ambang atas (N) dan ambang bawah (n) yang diperoleh dari hasil uji pendahuluan dengan jumlah perlakuan sebanyak tujuh konsentrasi dengan rumus (Anonimous, 1983) sebagai berikut:

$$
\log \frac{N}{n}=k\left(\log \frac{a}{n}\right)
$$

di mana

$$
\begin{array}{ll}
\mathrm{N}= & \text { Konsentrasi ambang atas } \\
\mathrm{n}= & \text { Konsentrasi ambang bawah } \\
\mathrm{k}= & \text { Banyaknya selang konsentrasi yang } \\
\mathrm{a}= & \text { akan diuji } \\
& \text { Konsentrasi terkecil dalam deretan } \\
& \text { konsentrasi setelah } \mathrm{n}
\end{array}
$$

Dari rumus (1) dapat diketahui nilai konsentrasi terkecil (a), kemudian dihitung konsentrasi b, c, $\mathrm{d}, \ldots, \mathrm{g}$ dengan menggunakan rumus (2) sebagai berikut:

$$
\frac{a}{n}=\frac{b}{a}=\frac{c}{b}=\frac{d}{c}=\frac{e}{d}=\frac{f}{e}=\frac{g}{f}
$$


Pada uji ini dilakukan pergantian air setiap 24 jam sebanyak $100 \%$ untuk mengurangi efek samping akibat berkurangnya daya racun logam berat, pembusukan ikan yang mati dan sisa pakan. Pemberian pakan sebanyak $3 \%$ bobot biomassa dilakukan dua jam sebelum pergantian air agar pakan yang tersisa tidak meracuni ikan.

Pemantauan kualitas air dilakukan untuk mengetahui dan mencegah efek negatif yang mungkin timbul akibat memburuknya kualitas air sehingga dapat mengaburkan hasil penelitian yang sebenarnya. Parameter kualitas air meliputi suhu air, $\mathrm{pH}$, salinitas, dan oksigen terlarut, dipantau pada awal percobaan dan setiap 24 jam atau sesaat sebelum dilakukan pergantian media dan akhir percobaan. Pengamatan hewan uji dilakukan pada jam ke-2, 4, 8, 16, 24, 48, 72, dan 96. Hewan uji yang mati segera dikeluarkan dari media percobaan agar tidak mempengaruhi kondisi kualitas air dan kehidupan hewan uji.

Untuk mengetahui nilai median lethal konsentrasi (LC50) pada waktu pemaparan 24, 48, 72 dan 96 jam, serta nilai interval masing-masing pada limit kepercayaan 95\%, data mortalitas yang diperoleh dianalisis dengan menggunakan bantuan perangkat lunak "Probit Analysis". Kondisi hewan uji dan kualitas air dianalisis secara deskriptif untuk mengetahui kelayakan media bagi kehidupan hewan uji.

\section{HASIL DAN PEMBAHASAN}

Hasil penelitian menunjukkan bahwa nilai ambang bawah bervariasi antara $10^{-2}-10^{2} \mathrm{ppm}$ dapat menimbulkan efek subletal atau kronis sedangkan untuk nilai ambang atas bervariasi antara $10^{-1}-10^{3}$, dapat menimbulkan efek letal pada benur windu dan nener bandeng (Tabel 1). Secara fisiologis efek tersebut disebabkan oleh menurunnya fungsi organ seperti insang, hati, ginjal, otot dan syaraf sehingga tidak berfungsi sebagaimana mestinya. Hal tersebut bila berlangsung secara terus-menerus akan mengakibatkan pengaruh letal.

Terdapat kecenderungan semakin tinggi konsentrasi logam berat dalam media, maka semakin banyak hewan uji yang mati. Diduga karena logam berat dalam perairan semakin banyak diserap oleh hewan uji sehingga efek toksiknya semakin kuat dan menyebabkan mortalitas pada benur windu dan nener bandeng.

Menurut Connel \& Miller (1995), pengaruh letal suatu bahan pencemar terhadap makhluk hidup adalah tanggapan yang terjadi pada saat zat-zat fisika atau kimia mengganggu proses sel

Tabel 1. Nilai LC0-48 jam dan LC100-24 jam (dalam ppm) terhadap benur windu dan nener bandeng pada uji pendahuluan.

Table 1. LCO-48hours and LC100-24hours (in ppm) values on post larvae of tiger prawn ( $P_{; j}$ monodon) and milkfish fry (C. chanos) at preliminary experiment.

\begin{tabular}{ccccc}
\hline \multirow{2}{*}{$\begin{array}{c}\text { Logam berat } \\
\text { Heavy metals }\end{array}$} & \multicolumn{2}{c}{$\begin{array}{c}\text { Benur windu } \\
\text { Post larvae of Tiger prawn }\end{array}$} & \multicolumn{2}{c}{$\begin{array}{c}\text { Nener bandeng } \\
\text { Milkfish fry }\end{array}$} \\
\cline { 2 - 5 } & LC0-48h & LC100-24h & LC0-48h & LC100-24h \\
\hline $\mathrm{Hg}$ & 0.01 & 0.1 & 0.1 & 10.0 \\
$\mathrm{Cd}$ & 0.10 & 10.0 & 10.0 & 100.0 \\
$\mathrm{Cu}$ & 1.00 & 100.0 & 1.0 & 10.0 \\
$\mathrm{~Pb}$ & 10.0 & 100.0 & 100.0 & $1,000.0$ \\
$\mathrm{Ni}$ & 10.0 & 100.0 & 100.0 & $1,000.0$ \\
$\mathrm{Cr}$ & 10.0 & 100.0 & 10.0 & 100.0 \\
\hline
\end{tabular}


atau subsel dalam makhluk hidup sampai suatu batas yang menyebabkan kematian secara langsung. Sebagai contoh, tidak dapat bernafas, gangguan dalam pergerakan untuk mendapatkan makanan atau menghindar dari pemangsa. Sedangkan pengaruh subletal adalah pengaruh yang merusak kegiatan fisiologi atau perilaku, tetapi tidak menyebabkan kematian langsung meskipun kematian dapat terjadi karena gangguan terhadap proses makan, pertumbuhan atau perilaku yang tidak normal, lebih mudah tertangkap pemangsa, kurangnya kemampuan berkelompok, atau sebab-sebab lain yang tidak langsung. Pengaruh ini tidak hanya menyebabkan perubahan dalam populasi individu, tetapi juga menyebabkan pergeseran komposisi dan diversifikasi spesies (GESAMP, 1971 dalam Connel \& Miller, 1995). Hasil penelitian Wong et al. (1993) menyimpulkan bahwa logam berat mungkin menjadi salah satu faktor lingkungan yang mengurangi rekruitmen udang penaeid dalam perairan estuari yang terpolusi berat di Hong Kong dan muara Sungai Zhujiang.

Wong et al. (1993), menyatakan bahwa logam berat dapat mempengaruhi secara nyata terhadap pengurangan predasi dan laju pemangsaan pascalarva Metapenaeus ensis terhadap nauplius Artemia. Tingkah laku makan $M$. ensis dipengaruhi oleh dosis subletal logam berat dan merupakan indikator stres lingkungan. Keberadaan logam berat dalam media pemeliharaan benur windu juga dapat mendorong proses kanibalisme karena terganggunya pergerakan individu sehingga mudah tertangkap sebagai akibat adanya konsentrasi logam berat dalam dosis subletal. Kematian benur windu sering didapatkan dalam kondisi tubuh tidak utuh, meskipun pakan diberikan dalam jumlah cukup. Hasil penelitian yang dikutip De Lisle \& Robert, Jr. (1994), menyatakan bahwa proses ganti kulit pada krustase euryhaline dipengaruhi oleh keberadaan logam berat $\mathrm{Cd}, \mathrm{Cr}, \mathrm{Cu}$, dan $\mathrm{Zn}$ dalam perairan. Stadia post-molt lebih sensitif dibandingkan dengan stadia pre atau inter-molt pada semua spesies yang melakukan ganti kulit. Pengamatan frekuensi ganti kulit pada benur udang windu, menunjukkan bahwa semakin tinggi dosis logam berat dalam media percobaan, maka jumlah individu yang mengalami ganti kulit semakin meningkat dan sebagian terjadi proses kegagalan ganti kulit sehingga mengakibatkan kematian pada benur udang windu. Diduga kematian udang disebabkan oleh keberadaan logam berat dalam dosis subletal yang mengakibatkan terganggunya pergerakan, individu sehingga mudah tertangkap serta kegagalan proses ganti kulit.

Hasil uji toksisitas akut menunjukkan bahwa semakin lama benur udang windu berada dalam medium percobaan, nilai konsentrasi logam berat yang mematikan $50 \%$ hewan uji (LC50) semakin rendah (Tabel 2), berarti keberadaan logam berat dalam medium semakin toksik terhadap kehidupan benur windu. Hubungan antara konsentrasi logam berat dan mortalitas pada setiap perlakuan membentuk suatu garis regresi dengan kemiringan (slope function) tertentu yang menggambarkan degradasi kekuatan efek toksik logam berat terhadap populasi hewan uji (Tabel 3). Dari analisis probit didapat kemiringan garis bervariasi antara 2,2632-5,0885 yang menunjukkan adanya respon benur udang windu yang bervariasi terhadap sifat toksik logam berat.

Dari hasil analisis probit (Tabel 2 dan 3) diketahui besarnya nilai konsentrasi yang dapat mematikan $50 \%$ populasi benur udang windu (LC50-96jam) adalah 0,0840 ppm (Hg); 0,8796 ppm (Cd); 1,8139 ppm (Cu); 14,5267 ppm (Pb); 19,8420 ppm (Ni); dan 22,8268 ppm (Cr), dengan nilai limit atas antara 0,1094-26,2074 ppm dan limit bawah antara $0,0702-20,0517 \mathrm{ppm}$. Sedangkan terhadap nener bandeng (Tabel 4 dan 5) masingmasing adalah $1,5444 \mathrm{ppm}(\mathrm{Hg}), 3,9316 \mathrm{ppm}(\mathrm{Cu})$, 14,7659 ppm (Cd), 40,7021 ppm (Cr), 86,925577 ppm $(\mathrm{Ni})$, dan $245,7488 \mathrm{ppm}(\mathrm{Pb})$ dengan nilai limit atas antara $1,7977-280,3563 \mathrm{ppm}$ dan limit bawah antara 1,3304-214,4518 ppm. Nilai LC50-96jam untuk logam $\mathrm{Hg}$ dan $\mathrm{Cd}$ adalah di bawah satu ppm untuk benur udang windu, lebih rendah dibandingkan dengan $\mathrm{Pb}, \mathrm{Ni}$, dan $\mathrm{Cr}$. Dari nilai tersebut dapat dinyatakan bahwa pada kondisi ini logam $\mathrm{Hg}$ dan $\mathrm{Cd}$ masing-masing 16-26 dan 173-272 kali lebih toksik terhadap kehidupan benur windu dibandingkan dengan logam $\mathrm{Pb}, \mathrm{Ni}$, dan $\mathrm{Cr}$. Respon yang relatif sama berlaku juga untuk nener bandeng. Wong et al. (1993), mendapatkan LC50-48jam logam berat $\mathrm{Cu}$ terhadap pascalarva Metapenaeus ensis lebih rendah dibandingkan dengan $\mathrm{Ni}$ dan $\mathrm{Cr}$, masingmasing 4,76; 8,85; dan 13,62 ppm. LC50-96jam Cu terhadap larva lobster Homarus americanus adalah 0,05 ppm (Johnson \& Gentile dalam Wong et al., 1993) dan 0,1 ppm untuk lobster dewasa (McLeese, 1974). 
Tabel 2. Nilai LC50-24, 48, 72, dan 96jam (dalam ppm) berbagai logam berat pada benur udang windu. Table 2. LC50-24,48,72, and 96hours values (in ppm) for different heavy metals on tiger prawn (P.monodon) post larvae.

\begin{tabular}{ccccc}
\hline \multirow{2}{*}{$\begin{array}{c}\text { Logam berat } \\
\text { Heavy metals }\end{array}$} & \multicolumn{4}{c}{$\begin{array}{c}\text { Waktu dedah (jam) } \\
\text { Exposure time (hours) }\end{array}$} \\
\cline { 2 - 5 } & $\mathbf{2 4}$ & $\mathbf{4 8}$ & $\mathbf{7 2}$ & $\mathbf{9 6}$ \\
\hline $\mathrm{Hg}$ & - & 0.2082 & 0.1315 & 0.0840 \\
$\mathrm{Cd}$ & - & 1.7666 & 1.2681 & 0.8796 \\
$\mathrm{Cu}$ & 29.1216 & 12.8799 & 4.3649 & 1.8139 \\
$\mathrm{~Pb}$ & 45.7718 & 43.6230 & 25.8247 & 14.5267 \\
$\mathrm{Ni}$ & 83.2403 & 41.9508 & 28.8518 & 19.8420 \\
$\mathrm{Cr}$ & - & 39.9745 & 30.2009 & 22.8268 \\
\hline
\end{tabular}

(-) tidak terhitung (uncountable)

Tabel 3. Garis probit nilai LC50-96jam berbagai logam berat pada benur udang windu.

Table 3. Probit lines of LC50-96hours for different heavy metals on post larvae of tiger prawn.

\begin{tabular}{ccccc}
\hline $\begin{array}{c}\text { Logam berat } \\
\text { Heavy metals }\end{array}$ & $\begin{array}{c}\text { LC50-96h } \\
(\mathbf{p p m})\end{array}$ & $\begin{array}{c}\text { Garis probit } \\
\text { Probit line }\end{array}$ & $\begin{array}{c}\text { Limit kepercayaan 95\% } \\
\text { The 95\% confidence } \\
\text { limit for LC50 }\end{array}$ & $\begin{array}{c}\text { Kriteria toksisitas } \\
\text { Toxicity criteria }\end{array}$ \\
\hline $\mathrm{Hg}$ & 0.0840 & $0.9682+2.2632 \mathrm{X}$ & $(0.0702<\mathrm{X}<0.1094)$ & sangat toksik (very toxic) \\
$\mathrm{Cd}$ & 0.8796 & $1.1365+2.3295 \mathrm{X}$ & $(0.7327<\mathrm{X}<1.0406)$ & sangat toksik (very toxic) \\
$\mathrm{Cu}$ & 1.8139 & $2.2911+4.5562 \mathrm{X}$ & $(3.4764<\mathrm{X}<4.4568)$ & sangat toksik (very toxic) \\
$\mathrm{Pb}$ & 14.5267 & $2.1313+2.4684 \mathrm{X}$ & $(7.7008<\mathrm{X}<18.9320)$ & sangat toksik (very toxic) \\
$\mathrm{Ni}$ & 19.8420 & $-1.6027+5.0885 \mathrm{X}$ & $(18.0635<\mathrm{X}<21.5248)$ & sangat toksik (very toxic) \\
$\mathrm{Cr}$ & 22.8268 & $-1.3807+4.6971 \mathrm{X}$ & $(20.0517<\mathrm{X}<26.2074)$ & sangat toksik (very toxic) \\
\hline
\end{tabular}

Secara klinis hewan uji yang terkontaminasi logam berat memperlihatkan gejala stres bila dibandingkan dengan kontrol, ditandai dengan menurunnya nafsu makan, gerakan kurang stabil, dan cenderung berada di dasar. Hal ini diduga sebagai suatu cara untuk memperkecil proses biokimia dalam tubuh yang teracuni, sehingga efek letal yang terjadi lebih lambat.
Gejala nafsu makan yang menurun diperlihatkan dengan tidak responnya hewan uji terhadap makanan yang diberikan dan secara visual terlihat dari keberadaan feses dalam usus dan sisa pakan yang menumpuk. Pada perlakuan kontrol, hewan uji memiliki sisa feses dalam usus yang panjang sebagai indikasi tingginya aktivitas makan. 
Tabel 4. Nilai LC50-24, 48, 72, dan 96jam (dalam ppm) berbagai logam berat terhadap nener bandeng. Table 4. LC50-24,48,72, and 96hours (in ppin) values for different heavy metals on milkfish fry.

\begin{tabular}{ccccc}
\hline \multirow{2}{*}{$\begin{array}{c}\text { Logam berat } \\
\text { Heavy metals }\end{array}$} & \multicolumn{4}{c}{$\begin{array}{c}\text { Waktu dedah (jam) } \\
\text { Exposure time (hours) }\end{array}$} \\
\cline { 2 - 5 } & $\mathbf{2 4}$ & $\mathbf{4 8}$ & $\mathbf{7 2}$ & $\mathbf{9 6}$ \\
\hline $\mathrm{Hg}$ & 2.6975 & 2.0253 & 1.7426 & 1.5444 \\
$\mathrm{Cd}$ & 33.2508 & 16.7535 & 15.8776 & 14.7659 \\
$\mathrm{Cu}$ & 5.5051 & 4.6875 & 4.5727 & 3.9316 \\
$\mathrm{~Pb}$ & 292.2902 & 282.7213 & 281.5233 & 245.7488 \\
$\mathrm{Ni}$ & 221.3567 & 151.1232 & 115.5616 & 86.9257 \\
$\mathrm{Cr}$ & 92.3163 & 65.5125 & 52.0254 & 40.7021
\end{tabular}

Tabel 5. Garis probit LC50-96jam berbagai logam berat terhadap nener bandeng. Table 5. Probit lines of LC50-96hour's for different heavy metals on milkfish fry.

\begin{tabular}{ccccc}
\hline $\begin{array}{c}\text { Logam berat } \\
\text { Heavy metals }\end{array}$ & $\begin{array}{c}\text { LC50-96h } \\
\text { (ppm) }\end{array}$ & $\begin{array}{c}\text { Garis probit } \\
\text { Probit line }\end{array}$ & $\begin{array}{c}\text { Limit kepercayaan 95\% } \\
\text { The 95\%confidence } \\
\text { limit for LC50 }\end{array}$ & $\begin{array}{c}\text { Kriteria toksisitas } \\
\text { Toxicity criteria }\end{array}$ \\
\hline $\mathrm{Hg}$ & 1.5444 & $-0.2138+2.7395 \mathrm{X}$ & $(1.3304<\mathrm{X}<1.7977)$ & sangat toksik (very toxic) \\
$\mathrm{Cd}$ & 14.7659 & $-1.0692+5.1906 \mathrm{X}$ & $(12.7553<\mathrm{X}<16.2961)$ & sangat toksik (very toxic) \\
$\mathrm{Cu}$ & 3.9316 & $2.2911+4.5562 \mathrm{X}$ & $(3.4764<\mathrm{X}<4.4568)$ & sangat toksik (very toxic) \\
$\mathrm{Pb}$ & 245.7488 & $-6.7659+5.8446 \mathrm{X}$ & $(214.4518<\mathrm{X}<280.3563)$ & toksik (toxic) \\
$\mathrm{Ni}$ & 86.9257 & $-6.3336+5.8446 \mathrm{X}$ & $(37.3653<\mathrm{X}<106.8421)$ & toksik (toxic) \\
$\mathrm{Cr}$ & 40.7021 & $-8.0858+8.1298 \mathrm{X}$ & $(38.2212<\mathrm{X}<43.4838)$ & sangat toksik (very toxic) \\
\hline
\end{tabular}

Secara umum mekanisme toksisitas ion-ion logam terhadap individu dibagi ke dalam tiga kategori, yaitu (1) menahan gugus fungsi biologis yang esensial dalam biomolekul, misalnya protein dan enzim, (2) menggantikan ion-ion logam esensial dalam biomolekul, dan (3) mengubah konformasi aktif biomolekul (Ochiai, 1971 dalam Connel \& Miller, 1995). Ion-ion logam $\mathrm{Hg}, \mathrm{Cu}$, $\mathrm{Pb}$ (IV) paling toksik menunjukkan mekanisme toksisitas berspektrum luas, dan efektif berikatan dengan kelompok gugus fungsi SH (sistein dan kelompok yang mengandung nitrogen antara lain lisin dan histidin imidazol pada pusat dalam enzim yang aktif mengkatalis). Bersama dengan beberapa ion-ion lain dapat membentuk organo- metalik yang larut dalam lemak dan mampu menembus membram biologis serta berakumulasi di dalam sel dan organel. Beberapa logam di dalam metalloprotein memperlihatkan kegiatan oksidasi-reduksi, seperti $\mathrm{Cu}^{2+}$ menjadi $\mathrm{Cu}^{+}$yang dapat mengubah integritas secara fungsional dan struktural. Logam $\mathrm{Cu}$ juga toksik pada $\mathrm{pH}$ 9, yang disebabkan ekskresi $\mathrm{CO}_{2}$ pada bagian insang yang memiliki $\mathrm{pH}$ rendah, sehingga ion hidroksida melepaskan $\mathrm{Cu}^{2+}$ bebas yang dapat diikat oleh epitelium insang (Sorensen, 1991).

Logam berat yang berada pada media air umumnya berbentuk ion seperti $\mathrm{Pb}^{2+}$ kemudian masuk ke dalam tubuh ikan melalui insang dan mulut melalui mekanisme osmoregulasi. Ion-ion 
logam dapat menggantikan ion-ion endogen lainnya. Sebagai contoh penggantian $\mathrm{Zn}^{2+}$ oleh $\mathrm{Ni}^{2+}$ di dalam enzim, seperti karbonat anhidrase, menyebabkan pengurangan aktivitas enzim. Juga penggantian $\mathrm{Ca}^{2+}$ di dalam protein membran menyebabkan kelainan fungsional (Connel \& Miller, 1995). Kemudian melalui jalan darah akan menyebar dan menumpuk (bioacumulation) pada organ-organ tubuh seperti hati, ginjal, limfa dan daging, sebagian akan diekskresikan lagi ke luar tubuh bersamaan dengan keluarnya urin, feses, dan mucus (Heath, 1987).

Hewan uji yang teracuni logam $\mathrm{Pb}$ terlihat bagian abdomen menghitam, hal ini disebabkan oleh pengaruh toksik logam $\mathrm{Pb}$ ke dalam organ tubuh melalui jalan darah seperti hati, jantung, limfa, ginjal, daging dan usus. Logam $\mathrm{Pb}$ mengakibatkan kerusakan pada eritrosit darah dan menyebabkan anemia dengan menghambat sintesis hemoglobin (Hernberg dalam Heath, 1987). $\mathrm{Pb}$ menghambat pembentukan enzim delta amino leuvolovic acid dehidrase (ALA-D) yang dibutuhkan pada tahap awal pembuatan hemoglobin dalam jaringan hemopoetik. Terhambatnya pembentukan enzim ALA-D oleh $\mathrm{Pb}$ sangat spesifik dibandingkan dengan logam berat lain seperti Cd yang tidak menghambat (Heath, 1987). Kematian hewan uji diduga akibat akumulasi logam berat dalam jaringan. Hal ini sesuai dengan penelitian Christensen \& Hunt dalam Heath (1987) yang mendapatkan adanya akumulasi logam berat $\mathrm{Pb}$ dalam organ ikan estuari, di antaranya berada di limpa, insang, sirip dan usus. Rachmansyah (1997) memperoleh adanya hubungan erat antara kondisi salinitas dengan laju akumulasi $\mathrm{Pb}$ dalam daging, organ dalam, dan eksoskeleton pada udang windu.

Produksi mukosa yang berlebih sebagai respon terhadap keberadaan logam berat ditandai dengan koagulasi lapisan anoxia, sehingga terjadi kekurangan oksigen akibat presipitasi $\mathrm{Cd}$ dalam mukosa yang menutupi filamen-filamen insang ikan (Sorensen, 1991). Lebih lanjut dinyatakan, penyebab kematian ikan akibat keracunan $\mathrm{Cd}$ disebabkan kombinasi beberapa faktor di antaranya produksi mukosa, hambatan terhadap acetylcholinesterase, depresi pusat respirasi, hypocalcemia, dan kerusakan insang.

Analisis kualitas air media menunjukkan nilai dalam batas-batas yang cukup layak bagi kehidupan hewan uji. Nilai salinitas adalah 20 ppt, suhu air berkisar $27-28^{\circ} \mathrm{C}, \mathrm{pH}$ sekitar $7-8$ dan oksigen terlarut antara 5,9-7,2 ppm (Tabel 6). Dari data yang diperoleh terlihat bahwa peubah kualitas air masih berada pada rentang yang layak bagi kehidupan benur udang windu dan nener bandeng. Dengan demikian dapat dinyatakan bahwa respon hewan uji disebabkan oleh perlakuan yang dicobakan bukan diakibatkan oleh kondisi peubah kualitas air selain kandungan logam berat. Terdapat hubungan negatif antara toksisitas logam berat dengan salinitas. Semakin tinggi salinitas, nilai toksisitas (LC50-96jam) logam $\mathrm{Cr}$ semakin tinggi terhadap nener bandeng, C. chanos (Rahmawati, 1996), Zn terhadap rotifera, Brachionus plicatilis (Basiran, 1994), dan $\mathrm{Cu}$ terhadap juvenil "pompano" Trachinotus carolinus (Birdsong \& Avault, 1971 dalam Sorensen, 1991). Utama (1994) mendapatkan nilai $\mathrm{pH}$ air berpengaruh nyata terhadap nilai LC50-96jam logam $\mathrm{Fe}$ terhadap kehidupan nener bandeng, C. chanos (Tabel 7).

Bila dihubungkan dengan baku mutu limbah (SK No. 51/MENLH/10/1995) untuk industri soda kostik, pelapis logam, penyamakan kulit, tekstil, baterai kering dan cat maka kadar limbah cair untuk logam $\mathrm{Hg}$ dan $\mathrm{Cu}$ berada di atas nilai aman bagi benur udang windu, sementara logam $\mathrm{Cu}$ untuk nener bandeng (Tabel 8). Hal ini menunjukkan bahwa baku mutu limbah yang ditetapkan masih berpeluang sebagai pencemar potensial bagi lingkungan perairan terutama benur udang windu dan nener bandeng. Pencemaran logam berat melebihi kriteria baku mutu, akan menyebabkan efek subletal bagi benur udang windu dan nener bandeng serta akan berakibat letal bagi sekian banyak organisme perairan pantai lainnya yang lebih rentan dari benur udang windu dan nener bandeng. Kondisi paling peka suatu jenis dan stadium daur hidup organisme perairan akan menjadi yang paling mudah teracuni pencemaran logam berat. Sorensen (1991) menyatakan bahwa logam $\mathrm{Pb}$ dapat mereduksi daya tahan embrio organisme akuatik. Lebih lanjut dinyatakan, ikan kecil (pada awal daur hidup) lebih sensitif terhadap logam $\mathrm{Pb}$ dibandingkan ikan dewasa karena laju metabolik pada ikan kecil lebih tinggi. Sementara Zn dalam pemaparan kronis dapat mempengaruhi pertumbuhan, tingkah laku, reproduksi ikan, menghambat pemijahan, viabilitas telur, dan sintasan benih. Hasil penelitian Iman (1994), menunjukkan bahwa nilai LC50-96jam logam Zn 
terhadap kehidupan nauplius, zoea, dan mysis udang windu masing-masing adalah 0,$140 ; 0,257$; dan 0,565 ppm, lebih rendah dari kadar maksimum limbah cair logam $\mathrm{Zn}$ untuk industri soda kostik, pelapis logam, dan cat masingmasing 1,0 ppm serta industri baterai kering 0,2 ppm (Lampiran B, SK Menteri Lingkungan Hidup No. 51/MENLH/10/1995). Hal ini berarti baku mutu limbah cair logam Zn yang ditetapkan masih berpeluang mematikan larva udang windu.

Meningkatnya kegiatan industri, pemukiman, penambangan dan transportasi darat dan laut menjadi penyebab bertambahnya limbah logam berat ke dalam perairan. Kondisi tersebut akan memicu peningkatan kerusakan ekosistem wilayah pesisir, sehingga berdampak pada kegiatan ekonomi, kesehatan, dan sosial masyarakat. Pada manusia logam berat seperti $\mathrm{Pb}$ akan mengakibatkan anemia, kerusakan sistem syaraf, urinaria, dan mempengaruhi sistem reproduksi (Palar, 1994). Untuk mencegah kerusakan lebih lanjut maka diperlukan upaya pengelolaan kawasan pesisir yang terpadu, berkesinambungan dan berwawasan lingkungan bagi upaya memproduksi bahan pangan yang higienis dan aman bagi konsumen.

Tabel 6. Parameter kualitas air media uji selama penelitian.

Table 6. Water quality parameters monitored during experiment.

\begin{tabular}{|c|c|c|c|c|c|}
\hline $\begin{array}{l}\text { Logam berat } \\
\text { Heavy metals }\end{array}$ & $\begin{array}{l}\text { Spesies } \\
\text { Species }\end{array}$ & $\begin{array}{c}\text { Suhu air } \\
\text { Water } \\
\text { Temperature }\left({ }^{\circ} \mathrm{C}\right)\end{array}$ & pH & $\begin{array}{c}\text { Salinitas } \\
\text { Salinity } \\
\text { (ppt) }\end{array}$ & $\begin{array}{c}\text { Oksigen terlarut } \\
\text { Dissolved oxygen } \\
\text { (ppm) }\end{array}$ \\
\hline \multirow[t]{2}{*}{$\mathrm{Hg}$} & $\begin{array}{l}\text { Udang windu } \\
\text { Tiger prawn }\end{array}$ & $28.55 \pm 0.78$ & $8.4 \pm 0.10$ & 25 & $5.65 \pm 0.23$ \\
\hline & $\begin{array}{l}\text { Ikan bandeng } \\
\text { Milkfish }\end{array}$ & $27.95 \pm 0.85$ & $8.4 \pm 0.37$ & 20 & $4.87 \pm 0.43$ \\
\hline \multirow[t]{2}{*}{$\mathrm{Cd}$} & $\begin{array}{l}\text { Udang windu } \\
\text { Tiger prawn }\end{array}$ & $27.86 \pm 0.85$ & $8.4 \pm 0.11$ & 25 & $5.61 \pm 0.10$ \\
\hline & $\begin{array}{l}\text { Ikan bandeng } \\
\text { Milkfish }\end{array}$ & $26.71 \pm 0.47$ & $7.6 \pm 0.47$ & 20 & $5.67 \pm 0.16$ \\
\hline \multirow[t]{2}{*}{$\mathrm{Cu}$} & $\begin{array}{l}\text { Udang windu } \\
\text { Tiger prawn }\end{array}$ & $28.01 \pm 0.73$ & $7.6 \pm 0.42$ & 20 & $5.32 \pm 0.68$ \\
\hline & $\begin{array}{l}\text { Ikan bandeng } \\
\text { Milkfish }\end{array}$ & $27.68 \pm 1.08$ & $7.5 \pm 0.31$ & 20 & $5.72 \pm 0.76$ \\
\hline \multirow[t]{2}{*}{$\mathrm{Pb}$} & $\begin{array}{l}\text { Udang windu } \\
\text { Tiger prawn }\end{array}$ & $26.58 \pm 0.76$ & $7.9 \pm 0.36$ & 20 & $5.62 \pm 0.68$ \\
\hline & $\begin{array}{l}\text { Ikan bandeng } \\
\text { Milkfish }\end{array}$ & $26.13 \pm 0.85$ & $8.0 \pm 0.20$ & 25 & $5.81 \pm 0.76$ \\
\hline \multirow[t]{2}{*}{$\mathrm{Ni}$} & $\begin{array}{l}\text { Udang windu } \\
\text { Tiger prawn }\end{array}$ & $27.54 \pm 0.65$ & $8.0 \pm 0.43$ & 20 & $4.91 \pm 1.09$ \\
\hline & $\begin{array}{l}\text { Ikan bandeng } \\
\text { Milkfish }\end{array}$ & $27.67 \pm 0.72$ & $7.9 \pm 0.46$ & 20 & $4.34 \pm 0.56$ \\
\hline \multirow[t]{2}{*}{$\mathrm{Cr}$} & $\begin{array}{l}\text { Udang windu } \\
\text { Tiger prawn }\end{array}$ & $27.54 \pm 0.37$ & $8.1 \pm 0.25$ & 30 & $6.07 \pm 0.98$ \\
\hline & $\begin{array}{l}\text { Ikan bandeng } \\
\text { Milkfish }\end{array}$ & $27.50 \pm 0.86$ & $7.8 \pm 0.11$ & 25 & $5.55 \pm 0.28$ \\
\hline
\end{tabular}


Tabel 7. Nilai LC50-96jam pada berbagai kondisi salinitas, $\mathrm{pH}$ dan organisme perairan.

Table 7. Values of LC50-96 hour at different salinities, $p H$, and organisms.

\begin{tabular}{|c|c|c|c|c|c|}
\hline $\begin{array}{l}\text { Logam berat } \\
\text { Heavy } \\
\text { metals }\end{array}$ & $\begin{array}{l}\text { LC50-96h } \\
\text { (ppm) }\end{array}$ & $\begin{array}{l}\text { Salinitas } \\
\text { Salinity } \\
\text { (ppt) }\end{array}$ & $\mathbf{p H}$ & $\begin{array}{l}\text { Spesies } \\
\text { Species }\end{array}$ & $\begin{array}{l}\text { Pustaka } \\
\text { References }\end{array}$ \\
\hline $\mathrm{Cr}$ & $\begin{array}{l}2.875 \\
3.398 \\
5.593\end{array}$ & $\begin{array}{l}10 \\
20 \\
30\end{array}$ & & Chanos chanos & Rahmawati (1996) \\
\hline $\mathrm{Cr}^{6+}$ & 1.23 & & & Cyprinodon variegatus & $\begin{array}{l}\text { Hutchinson } \\
\text { et al. (1994) }\end{array}$ \\
\hline $\mathrm{Cd}$ & 31.60 & & & Cyprinodon variegatus & $\begin{array}{l}\text { Hutchinson et al } \\
\text { (1994) }\end{array}$ \\
\hline $\mathrm{Cu}$ & $>0.22$ & & & Cyprinodon variegatus & $\begin{array}{c}\text { Hutchinson et al } \\
\text { (1994) }\end{array}$ \\
\hline $\mathrm{Cu}$ & $\begin{array}{l}1.42 \\
1.97\end{array}$ & $\begin{array}{l}10 \\
30\end{array}$ & & Trachinotus carolinus & $\begin{array}{l}\text { Birdsong dan Avault } \\
\text { (1971 dalam } \\
\text { Sorensen, 1991) }\end{array}$ \\
\hline $\mathrm{Zn}$ & $\begin{array}{l}0.140 \\
0.257 \\
0.565\end{array}$ & & & $\begin{array}{l}\text { Nauplius of tiger prawn } \\
\text { Zoea of tiger prawn } \\
\text { Mysis of tiger prawn }\end{array}$ & $\operatorname{Iman}(1994)$ \\
\hline $\mathrm{Fe}$ & $\begin{array}{l}11.70 \\
17.78 \\
29.51 \\
\end{array}$ & & $\begin{array}{l}5.5 \\
7.0 \\
8.5 \\
\end{array}$ & Chanos chanos & Utama (1994) \\
\hline
\end{tabular}

Tabel 8. Nilai aman logam berat (ppm) terhadap benur windu dan nener bandeng serta baku mutu limbah cair untuk kegiatan industri (ppm)

Table 8. Safe levels of heavy metals ( $\mathrm{ppm}$ ) on post larvae of tiger prawn and milk fish fry and waste water standard for industrial activities ( $\mathrm{ppm}$ )

\begin{tabular}{cccccccccc}
\hline $\begin{array}{c}\text { Logam } \\
\text { berat } \\
\begin{array}{c}\text { Heavy } \\
\text { metals }\end{array}\end{array}$ & \multicolumn{4}{c}{$\begin{array}{c}\text { Jenis kegiatan industri } \\
\text { Kinds of industrial activity*) }\end{array}$} & & \multicolumn{2}{c}{$\begin{array}{c}\text { Nilai aman } \\
\text { Safe level**) }\end{array}$} \\
\cline { 2 - 8 } & I & II & III & IV & V & VI & $\begin{array}{c}\text { Benur windu } \\
\text { Tiger prawn }\end{array}$ & $\begin{array}{c}\text { Nener bandeng } \\
\text { Milkfish }\end{array}$ \\
\hline $\mathrm{Hg}$ & 0.004 & - & - & - & $\underline{\mathbf{0 . 0 1}}$ & $\underline{\mathbf{0 . 0 1}}$ & $\underline{\mathbf{0 . 0 0 8}}$ & 0.154 \\
$\mathrm{Cd}$ & - & 0.05 & - & - & - & 0.08 & 0.087 & 1.476 \\
$\mathrm{Cu}$ & $\underline{\mathbf{1 . 0}}$ & $\underline{\mathbf{0 . 6}}$ & - & - & - & $\underline{\mathbf{0 . 8 0}}$ & $\underline{\mathbf{0 . 1 8 1}}$ & $\underline{\mathbf{0 . 3 9 3}}$ \\
$\mathrm{Pb}$ & 0.8 & 0.1 & - & - & - & 0.30 & 1.452 & 24.574 \\
$\mathrm{Ni}$ & 1.2 & 1.0 & - & - & 0.4 & - & 1.984 & 8.692 \\
$\mathrm{Cr}$ & 0.5 & 0.5 & 0.6 & 1.0 & 0.06 & - & 2.282 & 4.070 \\
\hline
\end{tabular}

*) Appendix B, Waste water standart for industrial activities (State Ministry Act for Environment No.KEP.51/ MENLH/10/1995). I (Sodium azide), II (Electrogalvanizing and electroplanting), III (Leather tanning and finishing), IV (Textile), V(Dry cell batteries), VI (Paint industry)

**) $S L=0,1 X$ LC50-96 hours (Wibisono, 1987) 


\section{KESIMPULAN DAN SARAN}

\section{Kesimpulan}

1. Logam berat $\mathrm{Cd}$ dan $\mathrm{Hg}$ bersifat sangat toksik terhadap kehidupan benur udang windu dan nener ikan bandeng. Sedangkan $\mathrm{Ni}, \mathrm{Cr}, \mathrm{Cu}, \mathrm{Pb}$ bersifat sangat toksik sampai toksik sedang, dengan urutan toksisitas $\mathrm{Hg}>\mathrm{Cd}>\mathrm{Cu}>\mathrm{Pb}>$ $\mathrm{Ni}>\mathrm{Cr}$ (benur udang windu), dan $\mathrm{Hg}>\mathrm{Cu}>$ $\mathrm{Cd}>\mathrm{Cr}>\mathrm{Ni}>\mathrm{Pb}$ (nener ikan bandeng).

2. Baku mutu iimbah cair logam $\mathrm{Hg}$ bagi kegiatan industri baterai kering dan cat berada di atas nilai aman untuk kehidupan benur windu, sementara logam $\mathrm{Cu}$ untuk kegiatan industri soda kostik, pelapis logam, dan cat berada di atas nilai aman untuk kehidupan benur windu dan nener bandeng. Nilai ini menunjukkan baku mutu limbah yang ditetapkan masih berpeluang mencemari lingkungan perairan terutama benur windu dan nener bandeng.

\section{Saran}

Pembuangan limbah yang mengandung logam berat ke dalam perairan perlu mempertimbangkan baku mutu air yang layak bagi kehidupan organisme perairan. Hasil studi ini perlu dijadikan informasi di dalam mengembangkan dan meninjau kembali penetapan baku mutu limbah terutama logam $\mathrm{Hg}$ dan $\mathrm{Cu}$ untuk jenis kegiatan soda kostik, pelapis logam, baterai kering, dan cat yang akan dibuang ke perairan, agar tidak berdampak negatif terhadap keberlanjutan manfaat perairan wilayah pesisir sebagai lingkungan hidup perikanan serta sintasan organisme perairan. Studi serupa perlu dilakukan terhadap jenis logam dan organisme lainnya terutama bagi stadium awal dari kehidupan organisme perairan yang umumnya memiliki tingkat kepekaan yang lebih tinggi terhadap cemaran logam berat.

\section{UCAPAN TERIMA KASIH}

Disampaikan kepada Reni Yulianingsih, Sutrisyani, Mat Fachrur, Rosni atas bantuannya di Laboratorium.

\section{DAFTAR PUSTAKA}

Anonim. 1983. Pedoman umum pengujian pestisida pada ikan untuk pendaftaran. Komisi Pestisida, Departemen Pertanian, Jakarta

Basiran. 1994. Daya racun dan pengaruh logam berat $\mathrm{Zn}$ terhadap populasi rotifer Brachionus plicatilis pada berbagai salinitas. Skripsi. Program Ilmu Kelautan, Universitas Diponegoro, Semarang.

Bryan, G.W. 1971. The effect of heavy metals (other than mercury) on marine and estuarine organism. Proc.Roy.Soc.Lond.B.,177:389-410.

Canli, M. and R.W. Furness. 1993. Toxicity of heavy metals dissolved in sea water and influences of sex and size on metal accumulation and tissue distribution in the Norway lobster Nephrops norvegicus. Marine Environmental Research, $36: 217-236$.

Connel, Des W., and G.J. Miller. 1995. Kimia dan ekotoksikologi pencemaran. Penerjemah, Yanti Koestoer; Pendamping, Sahati. Penerbit Universitas Indonesia, Jakarta. 520p.

De Lisle, P.F. and M.H. Robert, Jr. 1994. The effect of salinity on cadmium toxicity in the estuarine mysid Mysidopsis bahia: Role of osmoregulation and calcium. Marine Environmental Research, 37:47-62.

Frank, C.L.U. 1995. Toksikologi dasar. Penerbit Universitas Indonesia, Jakarta.

Heath, A.G., 1987. Water pollution and fish physiology. C.R.C. Press, Boston, Florida, AS. 245p.

Hutagalung, H.P. 1989. Mercury and cadmium content in green mussel, Mytilus viridis L. from Onrust Waters, Jakarta Bay. Bull.Environ.Contam.Toxicol. 42(6):323-324.

Hutagalung, H.P., A.G. Samad, S. Sidabutar. 1993. Kandungan logam berat dalam kerang hijau, Mytilus viridis yang dibudidayakan di perairan Ancol, Teluk Jakarta. Seminar Biologi Nasional di Universitas Hasanuddin, Ujung Pandang, 20-23 Juli 1993.

Hutchinson, T.H., T.D. Williams, and G.J. Eales. 1994. Toxicity of cadmium and copper to marine fish larvae (Cyprinodon variegatus) and copepods (Tisbe battagliai). Marine Environmental Research, 38:275-290.

Iman, M. 1994. Toksisitas logam berat $\mathrm{Zn}$ terhadap tingkat kematian, perkembangan dan pertumbuhan stadia larva udang windu. Skripsi. Program Ilmu Kelautan, Universitas Diponegoro, Semarang. 
McLeese, D.W. 1974. Toxicity of copper at two temperatures and three salinities to the american lobster Homarus americanus. J. Fish. Res. Board Can.,31:1949-52

Moriarty, P. 1987. Ecotoxicology. Second Edition. Academic Press, Harcout Jovanovich Publisher, London.

Palar, H. 1984. Pencemaran dan toksikologi logam berat. Penerbit Rineka Cipta, Jakarta.

Rachmansyah, Usman, dan Taufik Ahmad. 1997. Distribusi residu endosulfan dan logam berat di perairan pantai Sulawesi Selatan. J. Penelitian Perikanan Indonesia. (in press).

Rachmansyah. 1997. Akumulasi logam berat $(\mathrm{Pb})$ dalam tubuh udang windu, Penaeus monodon pada kondisi salinitas dan ukuran individu yang berbeda. Laporan Hasil Penelitian. Balai Penelitian Perikanan Pantai, Maros.
Rahmawati, U. 1996. Konsentrasi lethal LC50-96 logam berat $\mathrm{Cr}(\mathrm{VI})$ terhadap gelondongan bandeng (Chanos chanos) pada berbagai tingkat salinitas. Skripsi. Program Ilmu Kelautan, Universitas Diponegoro, Semarang.

Sorensen, E.B. 1991. Metal poisoning in fish. CRC Press, Inc, New York. 374p.

Utama, A.K. 1994. Daya racun lethal (LC50-96 jam) logam berat $\mathrm{Fe}$ terhadap nener bandeng (Chanos chanos) pada berbagai pH. Skripsi. Program Ilmu Kelautan, Universitas Diponegoro, Semarang.

Wibisono, M.S. 1987. Tingkat toksisitas minyak bumi nafterik intermediat terhadap beberapa jenis biota akuatik pantai. Lembaran Publikasi Lemigas. Jakarta. 21(3)

Wong, C.K., K.H. Chu, K.W. Tang, T.W. Tam and L.J. Wong. 1993. Effects if chromium, copper and nickle on survival and feeding behaviour of Metapenaeus ensis larvae and postlarvae (Decapoda:Penaeide). Marine Environmental Research, 36:63-7. 